\title{
Comparative proteomics reveals the physiological differences between winter tender shoots and spring tender shoots of a novel tea (Camellia sinensis L.) cultivar evergrowing in winter
}

Shengjie Liu ${ }^{1,3+}$, Jiadong Gao ${ }^{1+}$, Zhongjian Chen ${ }^{1}, X_{\text {Xaoyan }}$ Qiao ${ }^{2}$, Hualin Huang ${ }^{2}$, Baiyuan Cui ${ }^{1}$, Qingfeng Zhu', Zhangyan Dai ${ }^{1}$, Hualing $\mathrm{Wu}^{2}$, Yayan Pan ${ }^{1}$, Chengwei Yang ${ }^{3^{*}}$ and Jun Liu ${ }^{1,2^{*}}$

\begin{abstract}
Background: A recently discovered tea [Camellia sinensis (L.) O. Kuntze] cultivar can generate tender shoots in winter. We performed comparative proteomics to analyze the differentially accumulated proteins between winter and spring tender shoots of this clonal cultivar to reveal the physiological basis of its evergrowing character during winter.

Results: We extracted proteins from the winter and spring tender shoots (newly formed two leaves and a bud) of the evergrowing tea cultivar "Dongcha11" respectively. Thirty-three differentially accumulated high-confidence proteins were identified by matrix-assisted laser desorption ionization time of flight mass spectrometry (MALDI-TOF / TOF MS). Among these, 24 proteins had increased abundance while nine showed were decreased abundance in winter tender shoots as compared with the spring tender shoots. We categorized the differentially accumulated proteins into eight critical biological processes based on protein function annotation including photosynthesis, cell structure, protein synthesis \& destination, transporters, metabolism of sugars and polysaccharides, secondary metabolism, disease/defense and proteins with unknown functions. Proteins with increased abundance in winter tender shoots were mainly related to the processes of photosynthesis, cytoskeleton and protein synthesis, whereas those with decreased abundance were correlated to metabolism and the secondary metabolism of polyphenolic flavonoids. Biochemical analysis showed that the total contents of soluble sugar and amino acid were higher in winter tender shoots while tea polyphenols were lower as compared with spring tender shoots.

(Continued on next page)
\end{abstract}

\footnotetext{
* Correspondence: Yangchw@scnu.edu.cn; liujun@gdaas.cn; liujun139@139.com

${ }^{\dagger}$ Equal contributors

${ }^{3}$ Guangdong Key Lab of Biotechnology for Plant Development, College of

Life Science, South China Normal University, Guangzhou, Guangdong

510631, China

'Agro-biological Gene Research Center, Guangdong Academy of Agricultural

Sciences, Guangzhou, Guangdong 510640, China

Full list of author information is available at the end of the article
} 
(Continued from previous page)

Conclusions: Our study suggested that the simultaneous increase in the abundance of photosynthesis-related proteins rubisco, plastocyanin, and ATP synthase delta chain, metabolism-related proteins elF4 and protease subunits, and the cytoskeleton-structure associated proteins phosphatidylinositol transfer protein and profilin may be because of the adaptation of the evergrowing tea cultivar "Dongcha11" to low temperature and light conditions. Histone H4, Histone H2A.1, putative In2.1 protein and protein lin-28 homologs may also regulate the development of winter shoots and their response to adverse conditions.

Keywords: Tea (Camellia sinensis (L.) O. Kuntze), Tender shoots, Evergrowing in winter, Proteomics

\section{Background}

Tea [Camellia sinensis (L.) O. Kuntze] is an important non-alcoholic commercial beverage crop, which has unique aromatic and medicinal properties. Tea tree is a perennial plant, and winter dormancy is its biological adaptation to environmental changes $[1,2]$. As temperatures decrease in winter, the tea tender shoots gradually stop growing to form inert buds and enter a period of dormancy. An evergrowing winter tea individual was newly found from a landrace population in Yingde city in the field station of Tea Research Institute, Guangdong Academy of Agricultural Sciences. Unlike other regular tea trees that become dormant, this special individual generates tender shoots (apical bud and associated leaves), enabling it to grow in the winter (January). We propagated this unique individual to a clonal cultivar by grafting the single node cutting, and the evergrowing trait remained stable throughout years. This newly identified evergrowing tea tree cultivar "Dongcha11" can serve as a special resource for studying the physiological mechanism of evergrowing phenotype in winter.

Low temperature and insufficient sunshine during the winter curb the growth of tea buds, which enter dormancy in response to the ecological conditions unsuitable for growth $[1,3]$. Many studies have attempted to unravel the mechanism of winter dormancy in tea trees to study the regulation of gene expression [4-7]. Suppression subtractive hybridization analysis of cDNA libraries between dormant and sprouting buds of tea plant showed that the percentage of genes related to the formation of subcellular organelles and transporters was higher in the sprouting bud library while those related with antioxidant, translation regulator and response to stimulus showed a greater percentage in the dormant bud library [8]. Dormancy-related genes were identified by the analysis of dormant bud (Banjhi) specific transcriptome of tea (Camellia sinensis (L.) O. Kuntze) from a cDNA library [7]. The expression pattern of tea miRNAs in active and dormant bud were analyzed, and the role of target transcripts regulated by these miRNAs in relation to bud dormancy was discussed, but the molecular mechanism of tea plant dormancy remains unclear [4]. Apart from the studies related to dormancy, some reports have been focused on the adaptation of tea plants to cold environment, low temperature, and low light stress $[3,9]$. Analysis of global transcriptome profiles of Camellia sinensis during cold acclimation showed that the "carbohydrate metabolism" and "calcium signaling" pathways might play a vital role in tea plants' responses to cold stress [3]. However, the molecular mechanism governing the growth of buds and leaves of the evergrowing cultivar in winter is not known. So far, few studies have specifically reported on the growth of tea buds in winter, and only one closelyrelated report was about peach dormancy found in Mexico. Peach dormancy study reported the continuous growth of an evergrowing peach mutant in short-period light and low temperature [10-12]. The gene responsible for the evergrowing genotype was a dormancyassociated MADS-box (DAM) transcription factor. The DAM gene is expressed in wild-type peach trees, whereas it becomes silent in the mutant. The DAM gene is a member of the MADS-box family. Overexpression of another MADS-box gene, BpMADS4, prevents dormancy in Populus tremula [13].

The physiological and molecular differences between the winter tender shoots and spring tender shoots are the key to understanding the mechanism of development of winter tea tender shoots. Differences in gene expression leading to variation in the levels of their corresponding proteins directly affect the physiological processes in plants [14]. The differentially accumulated proteins detected by proteomic techniques between different tissues and organs under various stages and conditions reveal the molecular mechanisms involved in the developmental regulation, signal transduction, and metabolism. Proteomics is an invaluable tool for analyzing the differentially accumulated proteins under different environmental stimuli; however, this technology has not been fully exploited to elaborate the physiological and molecular differences between the various tea traits [15-18].

We conducted the present study to identify the differentially accumulated proteins between winter and spring tender shoots of the evergrowing tea cultivar "Dongcha11" through proteomics methods. Our study will 
provide novel insights into the physiological mechanism of tea tender shoots in response to low temperature and dim light stress.

\section{Methods}

Plant material

A tea tree plant which could grow tender shoots in winter was selected from a landrace tea population by Professors Jiaxian $\mathrm{Li}$ and Hualin Huang of Tea Research Institute, Guangdong Academy of Agricultural Sciences. The special individual plant was multiplied vegetatively by single node cuttings and became a clonal tea cultivar "Dongcha11". Dongcha11 were planted in Yingde $\left(24.30^{\circ}\right.$ $\mathrm{N}$ and $113.39^{\circ} \mathrm{E}$, lateritic red soil,pH 5.86,suitable for tea tree growth). Regular tea went to winter dormancy at the end of January 2013, whereas Dongcha11 continued to generate new tender shoots. Winter tender shoots were collected from Dongcha11 on 23rd January 2013, and spring tender shoots were collected from Dongcha11 on 2nd April 2013 respectively. Harvested samples were flash frozen in liquid nitrogen and stored in a $-80{ }^{\circ} \mathrm{C}$ freezer until further use.

\section{Methods \\ Tea protein extraction and content determination}

Protein extractions were performed as previously described [16] with minor modifications, sampling was done with three biological replicates. Briefly, $2 \mathrm{~g}$ tea winter tender shoots or spring tender shoots were randomly collected from Dongcha11 respectively and individually prepared for protein extraction, and each tea tender shoot sample was ground to a fine powder with $0.2 \mathrm{~g}$ PVPP in liquid nitrogen in a pre-cooled mortar. The powders were mixed with ice-cold TCA/acetone (containing $1 \%(v / v) \beta$-mercaptoethanol) and transferred into a $10 \mathrm{~mL}$ eppendorf tube. After centrifugation at $10,000 \times g$ for $10 \mathrm{~min}$ at $4{ }^{\circ} \mathrm{C}$, the pellet was washed twice with ice-cold acetone and dried in vacuum at $4{ }^{\circ} \mathrm{C}$ for $5 \mathrm{~min}$. Then, phenol (containing 0.5\% (w/v) DTT) was added to the pellet and the mixture was shaken vigorously at $4{ }^{\circ} \mathrm{C}$ for $30 \mathrm{~min}$ to facilitate the dissolution of proteins in phenol. The phenol solution was clarified by centrifugation at $12,000 \times g$ for $10 \mathrm{~min}$ at $4{ }^{\circ} \mathrm{C}$. The pellet was re-extracted using the same procedure and the supernatants were combined together. Proteins were precipitated by adding five volumes chilled methanol containing $0.1 \mathrm{M}$ ammonium acetate to the pooled supernatants and incubating overnight at $-20{ }^{\circ} \mathrm{C}$. The precipitated proteins were collected by centrifugation at $12,000 \times g$ for $10 \mathrm{~min}$ at $4{ }^{\circ} \mathrm{C}$. The protein pellet was washed twice with pre-cooled methanol and once with acetone, and then vacuum-dried at $4{ }^{\circ} \mathrm{C}$ for $5 \mathrm{~min}$. The resulting protein powder was stored at $-80{ }^{\circ} \mathrm{C}$ for future use. The protein concentration was determined by Bradford assay.

\section{Tea protein two-dimensional electrophoresis (2-DE) and image analysis}

For 2-DE, a total of $1.5 \mathrm{mg}$ protein was first subjected to isoelectric focusing (IEF) and then separated by 2nd dimension SDS-PAGE. First-dimension IEF was conducted using pH 3-10 NL IPG strips (ReadyStrip, $24 \mathrm{~cm}$, BioRad, USA). The strips were rehydrated in a rehydration solution containing the protein sample for $12 \mathrm{~h}$ at $20{ }^{\circ} \mathrm{C}$. IEF was performed on Protean ${ }^{\circ}$ IEF Cell (Bio-Rad) under voltage conditions ramping to $10,000 \mathrm{~V}$ within $8 \mathrm{~h}$, and then at $10,000 \mathrm{~V}$ until a total of $100-160 \mathrm{kVh}$ was reached.

After IEF, the strips were equilibrated immediately for $15 \mathrm{~min}$ in equilibration buffer $1(50 \mathrm{mM}$ Tris- $\mathrm{HCl}$, $\mathrm{pH}$ 8.8, $6 \mathrm{M}$ urea, 30\% ( $v / \mathrm{v})$ glycerol, $4 \%(w / v)$ SDS, $2 \%$ $(\mathrm{w} / \mathrm{v})$ DTT, $0.001 \%(\mathrm{w} / \mathrm{v})$ bromophenol blue), then $15 \mathrm{~mL}$ equilibration buffer $2(50 \mathrm{mM}$ Tris- $\mathrm{HCl}, \mathrm{pH} 8.8$, $6 \mathrm{M}$ urea, 30\% (v/v) glycerol, 4\% (w/v) SDS, 2.5\% (w/v) iodoacetamide, $0.001 \%(\mathrm{w} / \mathrm{v}))$ was added and incubated for $15 \mathrm{~min}$. Second dimension SDS-PAGE was performed in a $12.5 \%(\mathrm{v} / \mathrm{v})$ polyacrylamide-SDS gel (Protean $^{\circ}$ Plus Dodeca Cell, Bio-Rad). After electrophoresis, the gels were stained with Coomassie Brilliant Blue. Stained 2-DE gels were scanned with GS-800 Calibrated Densitometer (Bio-Rad), and data were analyzed by PDQuest software version 8.0 (Bio-Rad) as described by the manufacturer. The spots were detected by the software automatically and then subjected to careful manual editing and confirmation. Each spot included on the standard gel met the following criteria: it was present in at least two of the three gels and was qualitatively consistent in size and shape in the replicate gels. The relative volume of each spot was assumed to represent its expression level. After manual examination, the volume of each well-separated spot was compared between winter and spring tender shoots to identify differentially accumulated protein spots. The statistical significance of the quantitative data was determined using a Student's $t$ test. A spot abundance ratio of greater than $2.0(p<0.05)$ (a spot present uniquely or present in two-fold abundance in one sample relative to the other) was used as the threshold for a protein being differentially accumulated in subsequent studies.

\section{Mass spectrometry (MS) analysis for protein identification}

Differentially expressed protein spots were excised and digested with trypsin (Promega, Madison, WI, USA). Gel slices were placed in $0.1 \mathrm{M} \mathrm{NH}_{4} \mathrm{HCO}_{3}$ in $30 \%(v / \mathrm{v})$ acetonitrile $(\mathrm{ACN})$, vortexed, and then destained for $15 \mathrm{~min}$. The gel pieces were washed twice with ACN and immersed in $5 \mu \mathrm{l} 2.5-10 \mathrm{ng} / \mu \mathrm{L}$ trypsin for 30 
60 min at $4{ }^{\circ} \mathrm{C}$. Trypsin-saturated gel pieces were depleted of excessive enzyme solution and digested in $20 \mu \mathrm{L} 25 \mathrm{mM} \mathrm{NH}_{4} \mathrm{HCO}_{3}(\mathrm{pH} 7.8-8.0)$ at $37^{\circ} \mathrm{C}$ for $20 \mathrm{~h}$. The peptides were extracted two times with $100 \mu \mathrm{L} 0.1 \%$ (v/v) TFA in $60 \%(\mathrm{v} / \mathrm{v})$ ACN. Extracts were pooled together and lyophilized. Lyophilized peptides were reconstituted with $3 \mu \mathrm{L} 0.1 \%(\mathrm{v} / \mathrm{v})$ trifluoroacetic acid (TFA) in $30 \%(\mathrm{v} / \mathrm{v}) \mathrm{ACN}$. The resulting peptides were subjected to MALDI-TOF/TOF MS analysis (Ultraflextreme, Bruker, Bremen, Germany). Peptide mass data was analyzed using MASCOT (Matrix Science, London, UK). The acquired data were analyzed by searching the SwissProt and/or NCBI green plant database for identified proteins with Mascot software. The search parameters allowed for one missed cleavage, fixed modifications of pyridylethyl, and variable modifications of methionine oxidation and cysteine carboxyamidomethylation with a peptide mass tolerance of $100 \mathrm{ppm}$. The main criteria used for accepting an identified protein should be $p<0.05$.

\section{Quantitative RT-PCR analyses}

Total RNA was extracted from winter tender shoots or spring tender shoots individually using $1 \mathrm{~mL}$ of TRIzol reagent (Invitrogen). For all samples, $1 \mu \mathrm{g}$ of total RNA was converted to cDNA using PrimeScript ${ }^{\circ} 1$ st Strand cDNA Synthesis Kit (Takara) according to the manufacturer's instructions. Quantitative real-time PCR was performed with the SYBR ${ }^{\circ}$ Premix Ex Taq kit (Takara) and a Stratagene Mx3000P real-time PCR instrument (Agilent) using three-step cycling conditions of $95{ }^{\circ} \mathrm{C}$ for $5 \mathrm{~min}$ followed by 40 cycles of $95{ }^{\circ} \mathrm{C}$ for $10 \mathrm{~s}, 58{ }^{\circ} \mathrm{C}$ for $20 \mathrm{~s}$ and $72{ }^{\circ} \mathrm{C}$ for $20 \mathrm{~s}$. The reaction mixture $(20 \mu \mathrm{L})$ contained $1 \mu \mathrm{L}$ of cDNA solution, $10 \mu \mathrm{L}$ SYBR $^{\circ}$ Premix Ex Taq and primers at a concentration of $6 \mu \mathrm{M}$ each. All gene-specific primers (Additional file 1: Table S1) were designed using the Primer Version 5.0 (PREMIER Biosoft International) and were based on the cDNA sequences. The tea gene ubiquitin (UBI) was used as a reference for calculating relative transcript abundance. The primers are: forward (5'-CAGGACAAAGAGGGCATACC-3') and reverse (5'-CACGCAATCGGAGAACCAAG-3'). The relative quantification of RNA expression was calibrated using formula $2^{-\Delta \Delta \mathrm{Ct}}$ method. Samples of winter tender shoots and spring tender shoots were three biological replicates with three technical replicates.

\section{Biochemical measurements}

Tea sample production and processing methods refer to "Descriptors and Data Standard for Tea (Camellia spp.)" approach [19]. Moisture measurement was referred to GB / T 8304-2002 using the $103{ }^{\circ} \mathrm{C}$ constant weight method. Water extracts were measured according to GB / $\mathrm{T}$ 8305-2002. Determination of polyphenols was referred to GB / T 8313-2008. Determining the contents of free amino acids was referred to GB / T 8314-2002, and soluble sugars were carried out as previously described [20].

\section{Results \\ Comparison of proteomic profiles and identification of differentially accumulated proteins between winter and spring tender shoots}

We identified 42 protein spots on the 2-DE gel images that accumulated differentially (more than 2-fold in abundance) between the winter and spring tender shoots $(p<0.05)$ with the MALDI-TOF/TOF MS analysis. From these protein spots, 36 differentially accumulated proteins were retrieved from the SwissProt and NCBInr databases by Mascot analysis. Among them, three out of 36 differentially accumulated proteins were identified as a mixture of multiple proteins. Therefore, these proteins were excluded from the further analysis. The remaining 33 proteins included 24 proteins with increased abundance (Table 1) and nine with decreased abundance (Table 2) in winter tender shoots as compared with the spring shoots (Fig. 1, Additional file 2: Table S2).

The remaining 33 identified protein spots corresponded to 29 unique differentially abundant proteins because several spots represented identical proteins (spots 1 and 2, spots 3 and 4, spots 5 and 6, spots 16 and 17). Among the 29 unique proteins, 26 had known functions, whereas three had a predicted or unknown function.

\section{Functional classification of identified proteins was distinctly different between winter and spring tender shoots}

We categorized the 33 differentially accumulated proteins between winter and spring tender shoots into eight groups based on their potential physiological functions or involvement in different biological processes as described $[15,16]$ such as photosynthesis, cell structure (cytoskeleton and chromosomes), protein synthesis \& destination, transporters, sugars and polysaccharides, secondary metabolism, disease/defense, and protein of unknown functions (Tables 1 and 2).

The majority of differentially accumulated proteins (spots 1-10) were associated with photosynthesis followed by a cellular structure with five spots (including two cytoskeletal proteins (spots 12 and 13), and three chromosome proteins (spots 11, 14 and 15). Four protein spots (spots 22, 23, 30 and 31) were identified as disease resistant/defense proteins. Four other protein spots (spots 16, 17, 18 and 19) were in the protein 
Table 1 Proteins with increased abundance in "Dongcha11" shoots newly germinated in winter compared to spring tender shoots

\begin{tabular}{|c|c|c|c|c|c|c|c|c|}
\hline $\begin{array}{l}\text { Spot } \\
\text { No. }\end{array}$ & Protein name & Species & Accession & Ratio & $\begin{array}{l}\text { Mascot } \\
\text { score }\end{array}$ & $\begin{array}{l}\text { MS } \\
\text { coverage } \%\end{array}$ & $\begin{array}{l}\text { Theoretical } \\
\mathrm{Mr} .(\mathrm{kDa}) / \mathrm{pl}\end{array}$ & $\begin{array}{l}\text { Expressed } \\
\mathrm{Mr} .(\mathrm{kDa}) / \mathrm{pl}\end{array}$ \\
\hline \multicolumn{9}{|c|}{ Photosynthesis } \\
\hline 1 & Ribulose 1,5-bisphosphate carboxylase & $\begin{array}{l}\text { Aralidium } \\
\text { pinnatifidu }\end{array}$ & AAG24624 & $>100$ & 80 & 5 & $52.13 / 6.2$ & $14.46 / 4.07$ \\
\hline 2 & Ribulose 1,5-bisphosphate carboxylase & $\begin{array}{l}\text { Aralidium } \\
\text { pinnatifidu }\end{array}$ & AAG24624 & 75.93 & 76 & 5 & $52.13 / 6.2$ & $14.74 / 4.46$ \\
\hline 3 & Ribulose bisphosphate carboxylase large chain & Acacia farnesiana & P93998 & 19.9 & 415 & 12 & $50.86 / 6.2$ & $20.22 / 6.00$ \\
\hline 4 & Ribulose bisphosphate carboxylase large chain & Acacia farnesiana & P93998 & 13.38 & 427 & 7 & $50.86 / 6.2$ & 18.93/5.03 \\
\hline 5 & Ribulose bisphosphate carboxylase large chain & Akania bidwillii & Q07281 & 5.62 & 126 & 8 & $52.31 / 6.2$ & $29.14 / 6.82$ \\
\hline 6 & Ribulose bisphosphate carboxylase large chain & Akania bidwillii & Q07281 & 3.81 & 355 & 13 & $52.31 / 6.2$ & $29.21 / 6.73$ \\
\hline 7 & Ribulose bisphosphate carboxylase large chain & $\begin{array}{l}\text { Begonia metallica X } \\
\text { sanguinea }\end{array}$ & P28383 & 3.02 & 308 & 15 & $49.17 / 6.6$ & $28.32 / 6.43$ \\
\hline 8 & $\begin{array}{l}\text { RuBisCO large subunit-binding protein subunit } \\
\text { alpha, chlorop }\end{array}$ & Brassica napus (Rape) & P21239 & 2.09 & 344 & 8 & $57.71 / 4.7$ & $59.74 / 4.07$ \\
\hline 9 & Plastocyanin & Capsella bursa-pastoris & P00294 & 2.51 & 65 & 24 & $10.43 / 4.1$ & $14.11 / 3.54$ \\
\hline 10 & ATP synthase delta chain, chloroplastic & Spinacia oleracea & P11402 & 5.77 & 47 & 6 & $27.66 / 5.7$ & $17.54 / 5.76$ \\
\hline \multicolumn{9}{|c|}{ Cell structure } \\
\hline 11 & Putative histone $\mathrm{H} 3$-like 5 & Vitis vinifer & Q9FKQ3 & $>100$ & 52 & 14 & $15.64 / 11.9$ & $15.19 / 6.22$ \\
\hline 12 & Profilin-1 & Ricinus communis & O82572 & 2.09 & 84 & 29 & $14.31 / 4.4$ & $12.31 / 3.61$ \\
\hline 13 & Profilin-A & Camellia sinensis & Q9FUD1 & 2.75 & 71 & 9 & $14.35 / 4.8$ & $12.72 / 3.73$ \\
\hline 14 & Histone H4 & Arabidopsis thaliana & P59259 & $>100$ & 42 & 13 & $11.40 / 12.0$ & $13.24 / 6.04$ \\
\hline 15 & Histone H2A.1 & Triticum aestivum & P02275 & $>100$ & 52 & 8 & $15.58 / 11.1$ & $16.08 / 6.49$ \\
\hline \multicolumn{9}{|c|}{ Protein synthesis \& destination } \\
\hline 16 & Predicted protein & Populus trichocarpa & XP_002301464 & 6.5 & 145 & 9 & $29.47 / 10.0$ & $17.32 / 4.19$ \\
\hline 17 & Predicted protein & Populus trichocarpa & XP_002301464 & 2.09 & 161 & 10 & $29.47 / 10.0$ & $17.21 / 4.42$ \\
\hline 18 & Proteasome subunit beta type- 6 & Arabidopsis thaliana & Q8LD27 & 3.89 & 51 & 6 & $25.19 / 5.2$ & $22.22 / 5.23$ \\
\hline 19 & Eukaryotic initiation factor $4 \mathrm{~A}-1$ & Oryza sativa Japonica & P35683 & $>100$ & 59 & 9 & $47.34 / 5.3$ & $45.58 / 5.79$ \\
\hline \multicolumn{9}{|c|}{ Transporters } \\
\hline 20 & Hypothetical protein & Camellia sinensis & AEC10968 & 6.97 & 99 & 8 & $24.67 / 10.4$ & $19.54 / 4.36$ \\
\hline 21 & $\begin{array}{l}\text { Phosphatidylglycerol/phosphatidylinositol } \\
\text { transfer protein } \mathrm{p}\end{array}$ & Camellia sinensis & AEC10983 & 11.57 & 139 & 25 & $16.96 / 4.8$ & $12.47 / 4.15$ \\
\hline \multicolumn{9}{|c|}{ Disease/defense } \\
\hline 22 & Putative $\ln 2.1$ protein & Triticum aestivum & CAA76758 & 9.94 & 56 & 4 & $27.25 / 5.3$ & $26.48 / 4.35$ \\
\hline 23 & Peptide methionine sulfoxide reductase & Solanum lycopersicum & P54153 & 10.56 & 88 & 7 & $22.25 / 6.1$ & $19.72 / 5.61$ \\
\hline \multicolumn{9}{|c|}{ Protein of unknown functions } \\
\hline 24 & unknown & Picea sitchensis & ADE77382 & 3.53 & 91 & 4 & $37.84 / 5.8$ & $32.90 / 4.11$ \\
\hline
\end{tabular}

Only protein spots that changed in abundance at least 2-fold in at least two of three replicates are included

Ratio: Protein abundance in winter shoots/ Protein abundance in spring shoots

synthesis category, and three (spots 25, 26 and 27) in metabolism/sugars and polysaccharides. Secondary metabolism proteins were mapped to 2 proteins spots (spots 28 and 29) (Fig. 1; Tables 1 and 2).

The differentially increased abundance proteins in winter tender shoots showed distinct differences in biological functions (Fig. 2). All identified proteins involved in photosynthesis, cell structure, and protein synthesis and destination were increased abundance in winter tender shoots. Contrastingly, differentially decreased abundance proteins in winter tender shoots were mainly involved in metabolism (sugars and polysaccharides) and secondary metabolism processes.

Some disease/defense-proteins had increased abundance in winter tender shoots, and others had increased abundance in spring tender shoots. The protein expression of peptide methionine sulfoxide reductase (spot 23) and putative In2.1 protein (spot 22) significantly increased in winter tender shoots, while protein lin-28 homolog (spot 31) accumulated more 
Table 2 Proteins with decreased abundance in "Dongcha11" shoots newly germinated in winter compared to spring tender shoots

\begin{tabular}{|c|c|c|c|c|c|c|c|c|}
\hline Spot No. & Protein name & Species & Accession & Ratio & $\begin{array}{l}\text { Mascot } \\
\text { score }\end{array}$ & $\begin{array}{l}\text { MS } \\
\text { coverage\% }\end{array}$ & $\begin{array}{l}\text { Theoretical } \\
\mathrm{Mr} .(\mathrm{kDa}) / \mathrm{pl}\end{array}$ & $\begin{array}{l}\text { Expressed } \\
\mathrm{Mr} .(\mathrm{kDa}) / \mathrm{pl}\end{array}$ \\
\hline \multicolumn{9}{|c|}{ Metabolism /Sugars and polysaccharides } \\
\hline 25 & Fructokinase & $\begin{array}{l}\text { Actinidia } \\
\text { eriantha }\end{array}$ & P37829 & 0.45 & 45 & 3 & $33.97 / 5.4$ & $32.18 / 5.16$ \\
\hline 26 & Phosphomannomutase & $\begin{array}{l}\text { Nicotiana } \\
\text { tabacum }\end{array}$ & Q1W375 & 0.05 & 37 & 7 & $28.79 / 5.7$ & $26.47 / 7.17$ \\
\hline 27 & Eukaryotic galactinol synthase & Camellia sinensis & AFR79417 & 0.19 & 59 & 6 & $33.78 / 6.0$ & $30.87 / 6.27$ \\
\hline \multicolumn{9}{|c|}{ Secondary metabolism } \\
\hline 28 & Flavonol synthase & Camellia sinensis & ABM88786 & 0.46 & 518 & 29 & $37.60 / 5.5$ & $38.57 / 5.42$ \\
\hline 29 & $\begin{array}{l}\text { Bifunctional 3-dehydroquinate dehydra } \\
\text { tase/shikimate dehydrog }\end{array}$ & $\begin{array}{l}\text { Arabidopsis } \\
\text { thaliana }\end{array}$ & Q9SQT8 & 0.12 & 58 & 1 & $66.10 / 6.4$ & $58.43 / 6.93$ \\
\hline \multicolumn{9}{|c|}{ Disease/defense } \\
\hline 30 & Monodehydroascorbate reductase & Camellia sinensis & $\mathrm{ACH} 87167$ & 0.46 & 53 & 3 & $47.37 / 6.0$ & $38.99 / 6.08$ \\
\hline 31 & PREDICTED: protein lin-28 homolog & $\begin{array}{l}\text { Brachypodium } \\
\text { distachyon }\end{array}$ & XP_003562975 & $<0.01$ & 58 & 13 & $19.64 / 5.9$ & $18.47 / 4.96$ \\
\hline \multicolumn{9}{|c|}{ Protein of unknown functions } \\
\hline 32 & Unknown & Picea sitchensis & ABK23421 & 0.49 & 70 & 5 & $42.93 / 9.5$ & $30.04 / 5.41$ \\
\hline 33 & Predicted protein & $\begin{array}{l}\text { Populus } \\
\text { trichocarpa }\end{array}$ & XP_002298565 & 0.41 & 86 & 4 & $56.61 / 5.8$ & $57.00 / 5.66$ \\
\hline
\end{tabular}

Only protein spots that changed in abundance at least 2-fold in at least two of three replicates are included

Ratio: Protein abundance in winter shoots/ Protein abundance in spring shoots

than 100-fold higher in spring tender shoots over in winter tender shoots.

\section{Changes in transcript abundance of differentially accumulated proteins between winter shoots and spring shoots}

To validate the expression of the identified proteins at the transcriptional level, we analyzed the differences in mRNA abundance between winter and spring tender shoots. We selected 11 genes from different functional categories for quantitative real-time PCR (qRT-PCR) analysis. These included: Ribulose 1,5-bisphosphate carboxylase, ATP synthase delta chain, Proteasome subunit beta type-6, Profilin-A, Eukaryotic initiation factor 4A-1, Histone H4, Putative In2.1 protein, Bifunctional 3dehydroquinate dehydratase, Eukaryoticgalactinol synthase, Monodehydroascorbate reductase, and Fructokinase (Fig. 3).

Among them, six differentially accumulated proteins showed similar changes in their mRNA expression such as proteins involved in photosynthesis (ribulose 1,5bisphosphate carboxylase, ATP synthase delta chain), protein synthesis and destination (proteasome subunit beta type-6), cytoskeleton (Profilin-A), disease/defense (putative In2.1 protein), and secondary metabolism (Bifunctional 3-dehydroquinate dehydratase) (Fig. 3 and Tables 1 and 2).

However, alteration in protein expression levels does not always correlate well with the changes in mRNA levels. In this study also, we observed discrepancies in the abundance of protein and mRNA, for example, Eukaryoticgalactinol synthase, monodehydroascorbate reductase, fructokinase, Eukaryotic initiation factor 4A1, Histone H4. Moreover, the abundance of histone $\mathrm{H} 4$ increased in winter tender shoots while their mRNA expression decreased in winter tender shoots, while fructokinase accumulation was high in spring tender shoots but its mRNA expression showed no significant changes between shoots harvested in winter and spring. The inconsistency between mRNA levels and protein levels can be attributed to post-transcriptional, translational, and post-translational regulation of gene expression. However, their modification to play a functional role in the shoots of the evergrowing Dongcha11 required further study.

\section{Analysis of biochemical components between winter shoots and spring shoots}

Water extracts (aqueous extract) between spring tender shoots and winter tender shoots did not show significant differences (Fig. 4). The freshness and the processed quality of the winter shoots are similar to that of spring shoots. The winter tender shoots contained a lower polyphenol content (29.98\%) as compared with spring tender shoots (42.75\%) (Fig. 4). This data was consistent with the finding that differentially accumulated proteins involved in secondary metabolism were decreased abundance in winter tender shoots in proteomic analysis. 


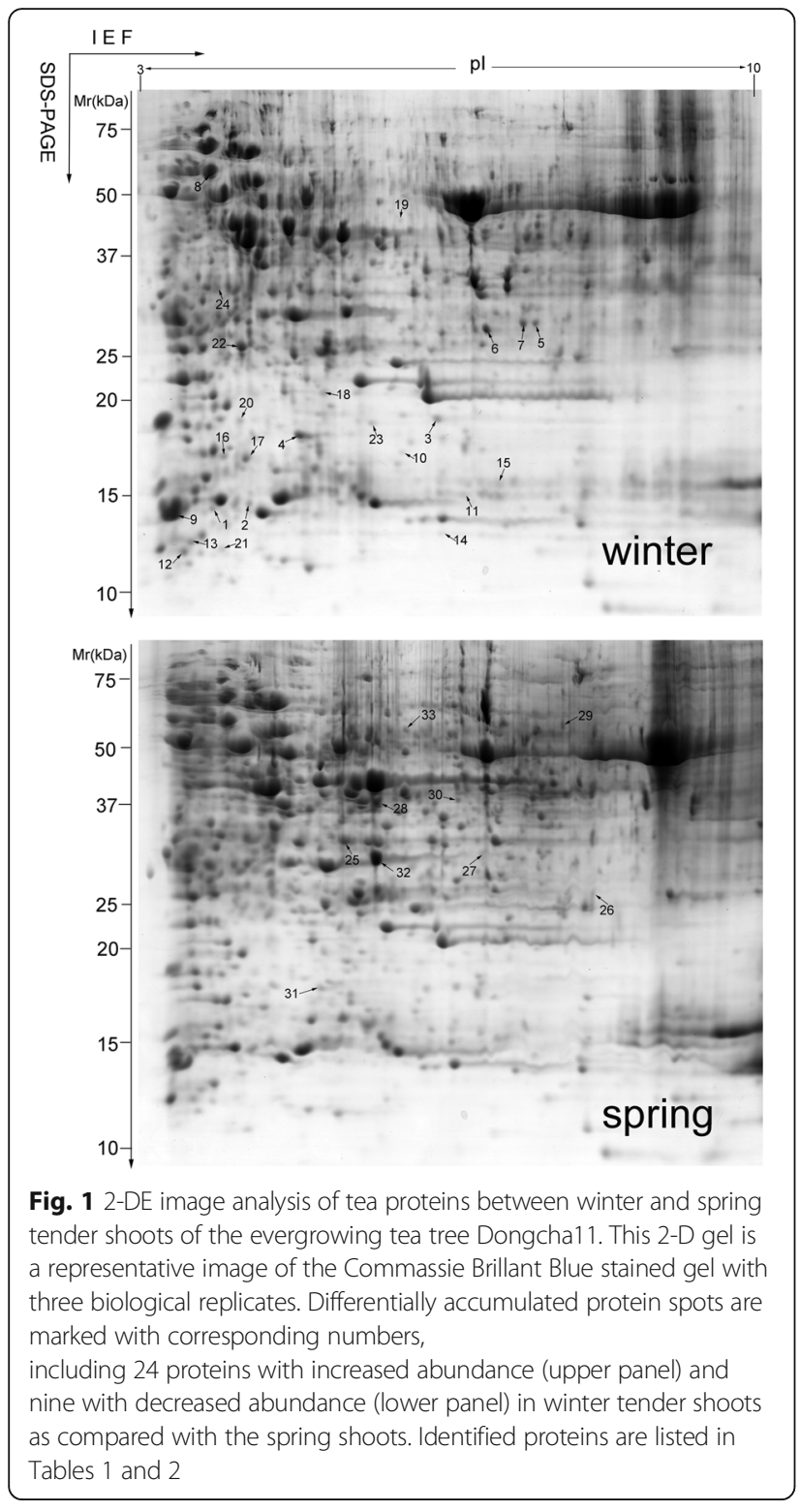

Total soluble sugar and amino acids contents were higher in winter tender shoots as compared with spring tender shoots (Fig. 4). The specific types of soluble sugars and/or amino acids in winter tender shoots require further research to determine the exact biological processes involved in the evergrowing phenotype in winter.

\section{Discussion}

\section{Differentially accumulated proteins involved in} photosynthesis increased significantly in winter tender shoots

All differentially accumulated proteins involved in photosynthesis showed dramatically increased abundance in winter tender shoots. These proteins are mainly associated with the dark reaction in photosynthesis

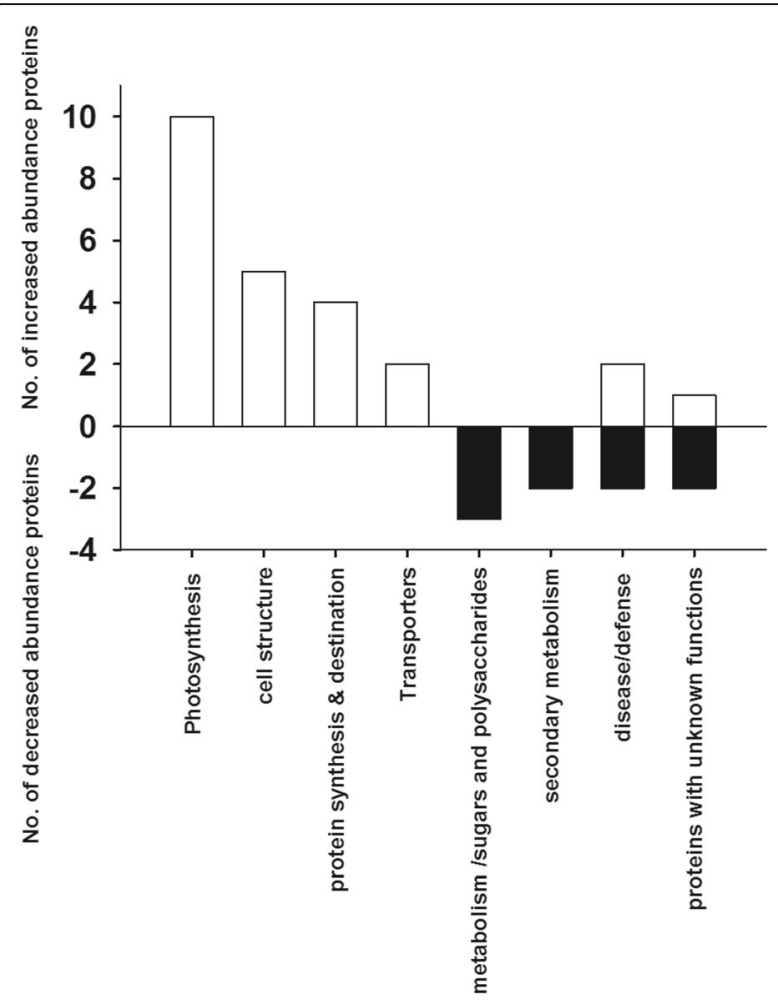

Fig. 2 The histogram represents the numbers of differentially increased and decreased abundance proteins in winter tender shoots in each functional category compared to spring tender shoots $\square$ No. of increased abundance proteins: Numbers of differentially increased abundance proteins in winter tender shoots, 24 protein spots were categorized into six functional groups. - No. of decreased abundance proteins: Numbers of differentially decreased abundance proteins in winter tender shoots, nine protein spots were categorized into four functional groups

(ribulose-1,5-bisphosphate carboxylase, ribulose-1,5bishosphatecarboxylase/oxygenase large subunit (RBCL), ribulose-1,5-bishosphate carboxylase/oxygenase large subunit-binding protein subunit alpha), photosynthetic phosphorylation pathway (plastocyanin), and chloroplast ATP synthase $\beta$ chain. Our qRT-PCR results demonstrated that these proteins showed a positive correlation between the transcriptional level and the protein level.

Previous studies have shown that low temperature and weak light caused blockage of plant electron transfer, decrease in carbon assimilation enzyme activity, and photosynthetic ability, and this adverse condition is an important cause for restriction in crop production [21]. Ribulose-1,5-bishosphate carboxylase/oxygenase is a key enzyme catalyzing the photosynthetic carbon cycle and the first reaction in photorespiration. Therefore, this enzyme plays an important role in regulating the rate of photosynthesis. Low temperature and dim light stress decrease Rubisco activase (RCA), Rubisco activity, and gene expression causing a decrease in net photosynthetic rate $(\mathrm{Pn})$ in cucumber seedlings [22]. 

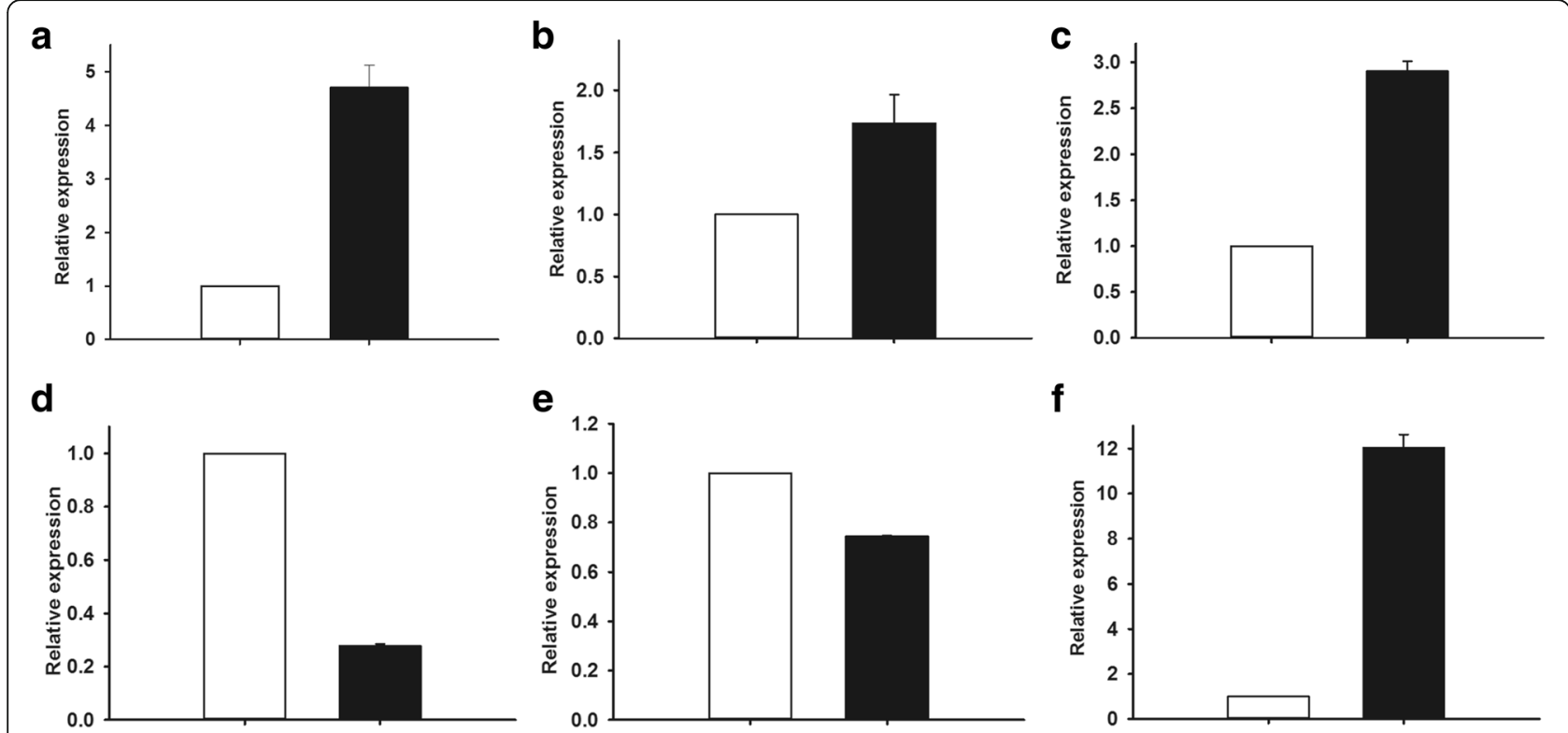

\section{f}
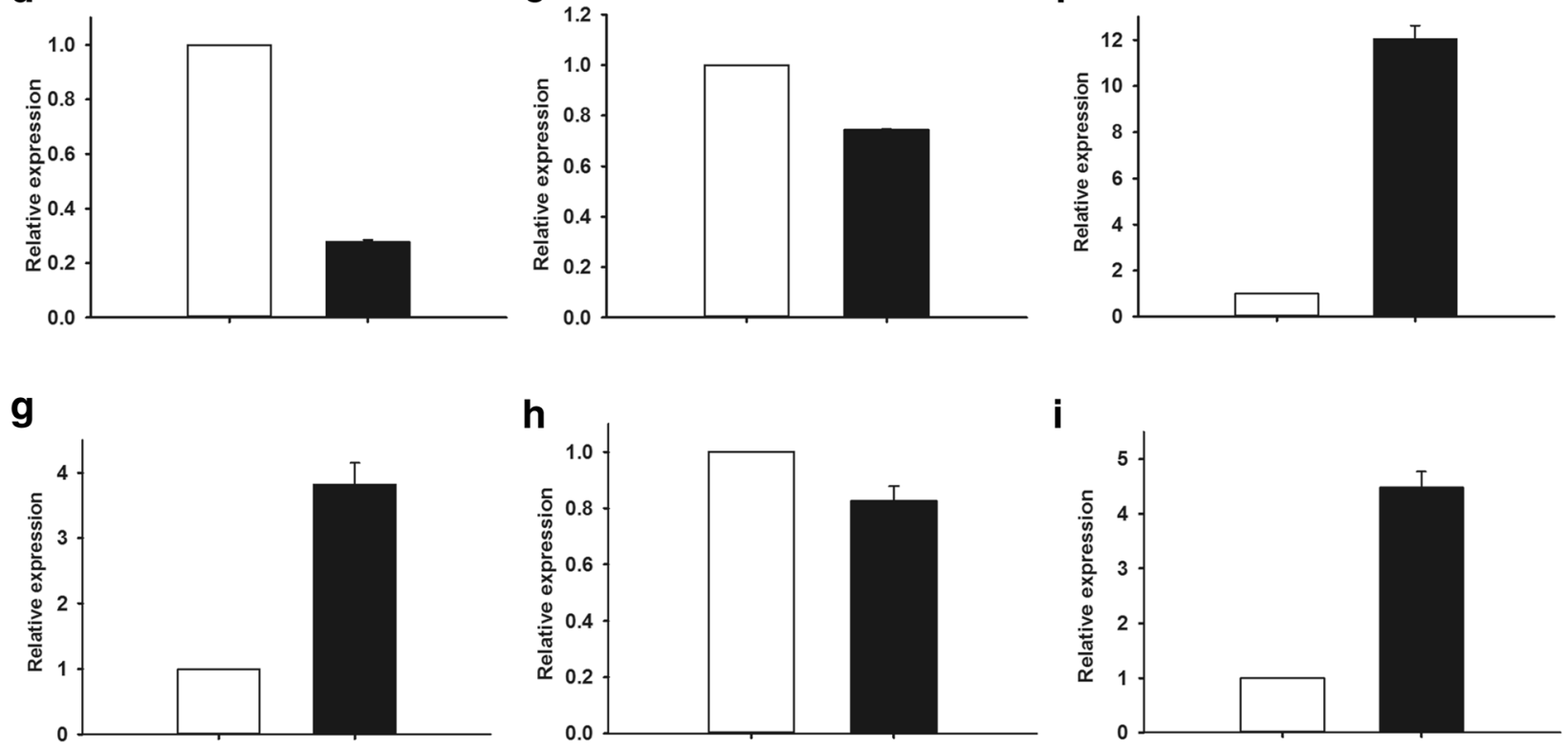

h

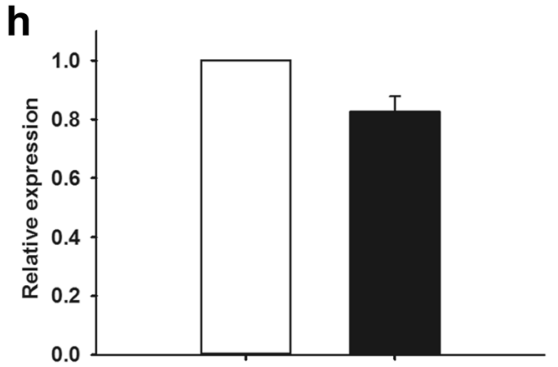

i

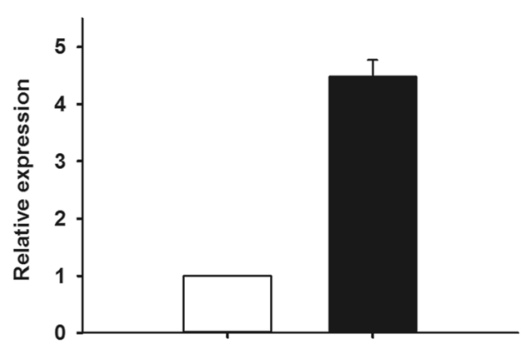

j

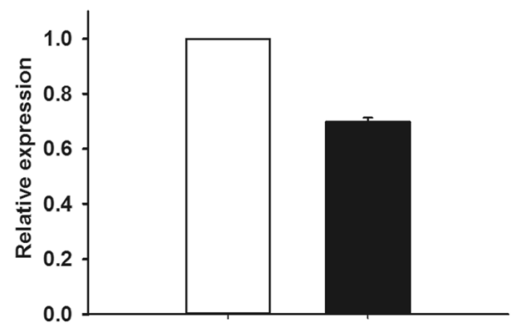

k

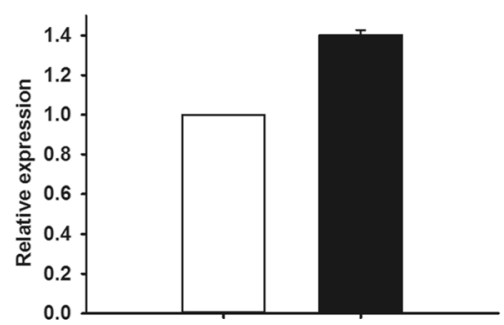

Fig. 3 Relative RNA levels of selected genes for corresponding differentially accumulated proteins by real-time RT-PCR between spring tender shoots and winter tender shoots. a: Ribulose 1,5-bisphosphate carboxylase; b: ATP synthase delta chain; c: Profilin-A; d: Histone H4; e: Eukaryotic initiation factor 4A-1; f: Proteasome subunit beta type-6; g: Putative In2.1 protein; h: Fructokinase partial; i: Eukaryotic galactinol synthase; j: Bifunctional 3-dehydroquinate dehydratase; $\mathbf{k}$ : Monodehydroascorbate reductase. Data are presented as the mean \pm SE of three biological replicates. $\square$ Spring tender shoots $\mathbf{a}$ Winter tender shoots

In our study, the protein abundances of Rubisco and electron mediator plastocyanin (PC) in photosynthetic phosphorylation pathway and ATP synthase delta chain dramatically increased in winter tender shoots. This abundance could be attributed to the adaption of Dongcha11 to low temperature and light stress. Plant photosynthetic efficiency declines in winter in response to low temperature and light. Dongcha11 probably increases the expression of photosynthesis proteins to maintain the normal physiological activity of evergrowing leaves in winter.

\section{Proteins involved in cell structure increased significantly} in winter tender shoots

Our data showed that several cytoskeleton-associated proteins were significantly increased abundance in 


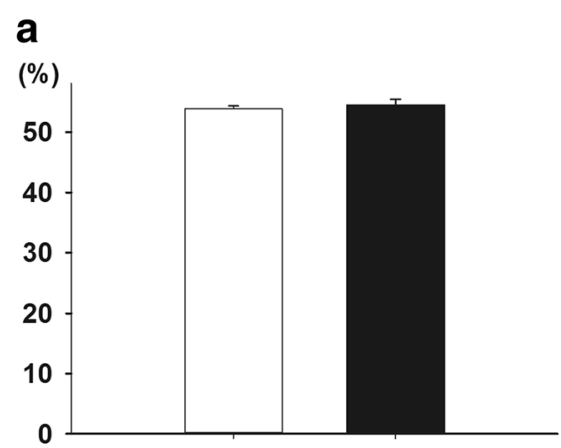

\section{C}

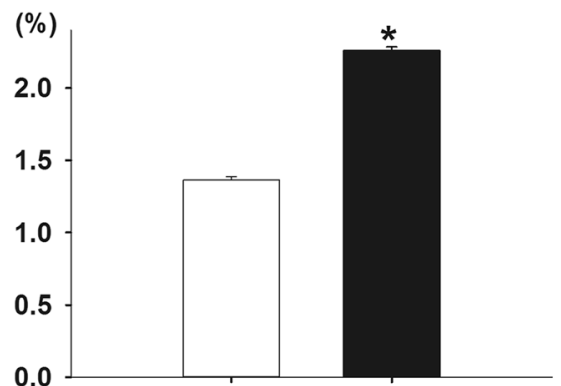

b
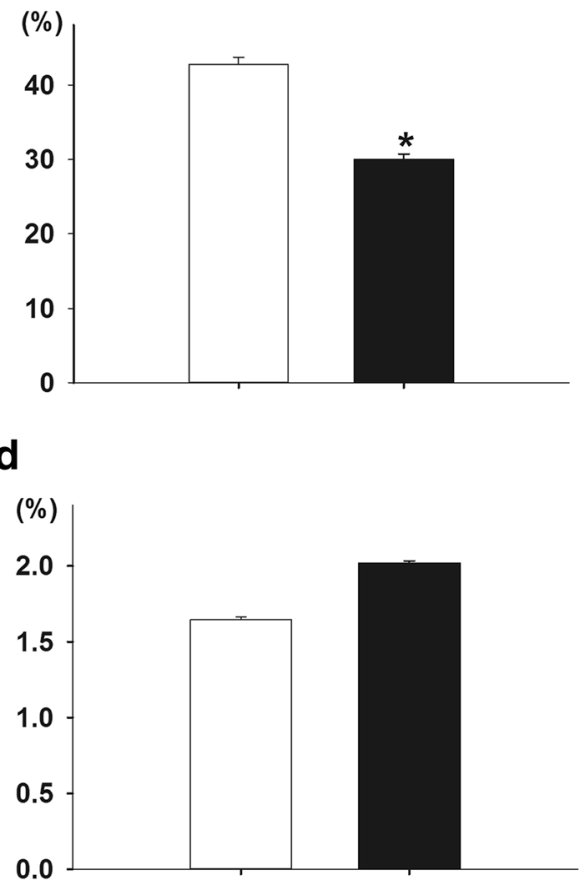

Fig. 4 The contents of water extracts, tea polyphenol, soluble sugar contents in winter shoots and spring shoots of the evergrowing tea tree Dongcha11. Different letters indicate groups with significant differences at $p=0.05$ (least significant difference-*), data are presented as the mean \pm SE of three replicates. $\mathbf{a}$ : Water extracts; $\mathbf{b}$ : Tea polyphenols; c: Soluble sugars; $\mathbf{d}$ : Free amino acids. $\square$ Spring tender shoots $\mathbf{m}$ Winter tender shoots

winter tender shoots, which was consistent with their mRNA expression (e.g., profilin-1 and profilin-A). Interestingly, phosphatidylinositol transfer protein (PITP) was also significantly increased abundance in the winter tender shoots.

Actin is a key player in the microfilament skeleton and maintains a dynamic balance between polymerization and depolymerization; thus, they can rapidly react to the stimulation from endogenous cellular factors or exogenous signals to ensure cellular homeostasis. A series of actin-binding proteins are involved in actin polymerization and depolymerization process [23]. As the first identified monomeric actin-binding protein, profilin is distributed widely in fast-growing root hairs and pollen tubes, and its activity is closely associated with pollen tube growth and root hair occurrence [24]. Arabidopsis seedlings deficient in profilin show abnormal development [23].

Profilin has binding sites with its ligand phosphatidylinosital biphosphate (PIP2) [25] and is located in the protruding parts of the root hair cells [26]. PITPs are capable of binding with phosphatidyl inositol (PI) or phosphatidylcholine and facilitate their transfer between intracellular membrane components [27, 28]. PITPs regulate the intercellular membrane transport system and phospholipid signal transduction playing a primary role in response to stress and regulation of development in higher plants [29]. In fact, PITPs function in tea tree dormancy [7]. Therefore, our result indicated that profilin and PITP may act synergistically through PIP2 to overcome the stress of low temperature and weak light in the evergrowing tea tree.

Histones are also associated with cell structure, and the abundance of Histone-like 5, Histone H4, and Histone H2A.1 was significantly increased in winter tender shoots. Post-translational modification of histone is closely related to chromosome remodeling and chromosome function, and also plays an important role in cell fate determination, cell growth, and other biological processes [30, 31]. Further, histone is essential to both dormancy and release of dormancy. Santamaría et al. found that chestnut genomic DNA methylation and histone H4 acetylation are closely associated with bud dormancy formation and release [32]. Fang et al. cloned cold resistant related H1-histone gene in tea [33]. It is noteworthy that in our study, differentially accumulated histone proteins showed a higher abundance in winter tender shoots while their mRNA transcripts were higher in their spring counterparts. This discrepancy may be due to a complicated regulatory role of histone involved in evergrowing in winter. 


\section{Proteins involved in protein synthesis increased} significantly in winter tender shoots

Four differentially accumulated proteins including eukaryotic translation initiation factor 4A (eIF4A), proteasome subunit beta type-6, and 2 predicted proteins were increased abundance in winter tender shoots.

Previous studies identified that eIF4A is an RNAbinding protein and functions as RNA helicase. EIF4A, eIF4E, and eIF4G form an eIF4F complex. This complex regulates the initiation of eukaryotic translation [34, 35]. Further studies showed that besides initiation of protein synthesis, eIF4A plays a key role in a series of biological processes such as signal transduction. eIF4A negatively regulates Dpp/BMP signaling in a translationindependent manner to promote Mad and Medea degradation in the SMAD complex during Drosophila embryo development [36]. Recent studies revealed that as a translation initiation factor, eIF4A, interacts with an oncogenic protein, thus, inhibiting the formation of eIF4F complex and negatively affecting the interaction of eIF4E-eIF4G and/or blocking the function of BRAF (V600) [37, 38]. The expression level of eIF4E in the eIF4F complex is correlated to that of matrix metalloproteinase MMP-9 $[39,40]$. In contrast, the function of eIF4A is not well-studied in plants. It was previously considered to function in response to abiotic stress and help improve crop yields under stress conditions [41]. Our finding that the protein abundance of eIF4A and protease subunits dramatically increased in winter tender shoots suggested their role in helping the evergrowing tea tree to overcome the environmental stress and maintaining growth and development in winter.

\section{Proteins involved in metabolism and secondary metabolism decreased significantly in winter tender shoots}

Compared to spring tender shoots, the differentially accumulated proteins related to carbohydrate metabolism (e.g. fructokinase, phosphomannomutase and eukaryotic galactinol synthase) significantly decreased in winter tender shoots.

Fructokinase is the first enzyme in the glycolytic pathway. As a key enzyme of fructose catabolism, fructokinase can also serve as a fructose sensor and a signaling molecule in plants. Therefore, it can influence metabolism and growth by regulating the plant life cycle [42].

Phosphomannomutase is a key enzyme in mannose metabolism that catalyzes the conversion of mannose-1phosphate to mannose-6-phosphate. Both fructokinase and phosphomannomutase are involved in the synthesis of vitamin $\mathrm{C}$ (ascorbic acid) in plants. Monodehydroascorbate reductase (MDHAR) plays an important role in the regeneration of vitamin $C$ (ascorbic acid). Ascorbic acid is oxidized to monodehydroascorbate (MDHA) by ascorbate peroxidase (APX). MDHA is highly unstable and is re-converted into ascorbic acid by MDHAR action [43].

Galactinol synthase functions in the first step of raffinose oligosaccharide family (RFO) synthesis, which is a key step for the synthesis and accumulation of RFO family members. RFO provides a carbon source for photosynthesis in plants growing at low temperature and also serves as a supplemental carbon source when starch metabolism in plants is suppressed under low temperatures [44]. However, the mechanism of galactinol synthase involved in the growth of winder tender shoots required further investigation.

In plants, synthesis of various phenolic compounds may depend on the shikimate pathway, phenylpropanoid pathway, and flavonoid biosynthetic pathway. Shikimate pathway is the main bridge between glucose metabolism and polyphenol metabolism. In the winter tender shoots, protein abundance of shikimate dehydrogenase (SDH) and dehydrogenation quinic acid (DHQ), and flavonol synthase of flavonoid biosynthesis pathway significantly decreased. In most microorganisms, DHQ and SDH are enzymes with a single function, but in plants, they may be fused to form a bifunctional enzyme. The advantage of DHQ-SDH compound in the shikimate pathway is that it can restrict the formation of intermediates; and thus, increases the turnover rate of metabolites [45]. In the flavonoid biosynthetic pathway, flavonol synthase (FLS) catalyzes flavanonols into flavonols [14, 46]. Both shikimate and flavonoid pathways regulate plant development and protect plants from UV and stress damage, which may contribute to the unique quality of specific plants. The shade treatment shows specific effects on different flavonoids of fresh tea leaves [47]. The specific effects include a reduction in the polymerization of catechins and glycosylation of flavonols and significant decrease expression of genes related to flavonoids synthesis such as PAL, F3H, F3'H, DFR, ANR, and UFGT. Moreover, flavonoid biosynthesis often increases in response to external stress factors such as light and cold temperature $[48,49]$. In our study, DHQ-SDH and FLS were of low abundance in the winter tender shoots. Biochemical analysis showed that the polyphenol content of spring tender shoots was significantly higher than their winter counterparts, which is in agreement with previous studies that light intensity impacts the synthesis of polyphenol secondary metabolites in plants [14].

\section{Conclusion}

Our study shows that differentially accumulated proteins between winter and spring shoots displayed specific functional classifications. Rubisco, and electron mediator PC and ATP synthase protein contents significantly increased in winter tender shoots indicating their role in 
maintaining normal growth under low temperatures and light conditions. An increase in other proteins such as eIF4A, protease subunits, phosphatidylinositol transfer protein (PITP), and profilin in winter tender shoots suggests that they might help in the development process of winter buds. The decrease in abundance of proteins involved in secondary metabolism corroborated the low content of tea polyphenols in winter.

To our knowledge, this is the first application of proteomics to reveal physiological and molecular characteristics of winter growing shoots of tea trees. Further research will combine non-gel proteomics with transcriptomic analysis to further analyze the expression patterns of the differentially accumulated proteins.

\section{Additional files}

Additional file 1: Table S1. Primers used in real-time RT-PCR for genes of differentially accumulated proteins in winter shoots and spring shoots. (DOC $23 \mathrm{~kb}$ )

Additional file 2: Table S2. Mascot identification data of the differentially accumulated proteins between winter and spring tender shoots of the evergrowing tea tree Dongcha11. (XLS $521 \mathrm{~kb}$ )

\section{Abbreviation \\ 2-DE: Two-dimensional electrophoresis; ACN: Acetonitrile; ADF: Actin- depolymerizing factor; APX: Ascorbate peroxidase; DAM: Dormancy- associated MADS-box; DHQ: Dehydrogenation quinic acid; elF4A: Eukaryotic translation initiation factor 4A; FLS: Flavonol synthase; GS: Galactinol synthase; IEF: Isoelectric focusing; MALDI-TOF / TOF MS: Matrix-assisted laser desorption ionization time of flight mass spectrometry; MDHA: Monodehydroascorbate; MDHAR: Monodehydroascorbate reductase; PC: Plastocyanin; PI: Phosphatidyl inositol; PIP2: Phosphatidylinositol bisphosphate; PITP: Phosphatidylinositol transfer protein; PMM: Phosphomannomutase; RBCL: Ribulose-1,5-bishosphatecarboxylase/ oxygenase large subunit; RCA: Rubisco activase; RFO: Raffinose oligosaccharide; SDH: Shikimate dehydrogenase}

\section{Acknowledgements}

This research was supported by Science Foundation of Guangdong Province (No. S2011010000689) and Guangdong Science and Technology plan project (No. 2011A020201005, 2013B060400038, 2016B030303007). We thank

Professor Jiaxian Li for providing the evergrowing tea tree "Dongcha11" and, Professor Dong Chen for providing advice on the project design. We also thank Haifeng Hu for his help in protein extraction and Yan Zhu for her help in biochemical analysis.

\section{Funding}

This research was supported by Science Foundation of Guangdong Province (No. S2011010000689) and Guangdong Science and Technology plan project (No. 2011A020201005, 2013B060400038, 2016B030303007).

The funding body(s) played no role in the design or conclusion of this study.

Availability of data and materials

All data and materials are included within the manuscript.

\section{Consent to publish}

Not applicable

\section{Authors' contributions}

SJL participated in conceiving the study, 2-DE analysis, data analysis and drafting the manuscript; JDG participated in conceiving the study, data analysis and drafting the manuscript; ZJC participated in data analysis and drafting the manuscript; $J L$ participated in conceiving the study, data analysis and drafting the manuscript; CWY participated in conceiving the study and data analysis; XYQ participated in physiological analysis; BYC participated in MALD I-TOF/TOF MS analysis; QFZ participated in the real time PCR analysis; ZYD participated in data analysis; HLW physiological analysis; HLH carrying out sample collection. All authors read and approved the final manuscript.

Ethics approval and consent to participate

Not applicable

\section{Competing interests}

The authors declare that they have no competing interests.

\section{Publisher's Note}

Springer Nature remains neutral with regard to jurisdictional claims in published maps and institutional affiliations.

\section{Author details}

${ }^{1}$ Agro-biological Gene Research Center, Guangdong Academy of Agricultural Sciences, Guangzhou, Guangdong 510640, China. ${ }^{2}$ Tea Research Institute, Guangdong Academy of Agricultural Sciences, Guangzhou, Guangdong 510640, China. ${ }^{3}$ Guangdong Key Lab of Biotechnology for Plant Development, College of Life Science, South China Normal University, Guangzhou, Guangdong 510631, China.

Received: 24 January 2017 Accepted: 31 October 2017

Published online: 20 November 2017

References

1. Barua DN. Seasonal dormancy in tea (Camellia Sinensis L.). Nature. 1969; 224(224):514.

2. Vyas D, Kumar S, Ahuja PS. Tea (Camellia Sinensis) clones with shorter periods of winter dormancy exhibit lower accumulation of reactive oxygen species. Tree Physiol. 2007;27:1253-9.

3. Wang X-C, Zhao Q-Y, Ma C-L, Zhang Z-H, Cao H-L, Kong Y-M, Yue C, Hao X$Y$, Chen L, Ma J-Q, et al. Global transcriptome profiles of Camellia Sinensis during cold acclimation. BMC Genomics. 2013;14:415.

4. Jeyaraj A, Chandran V, Gajjeraman P. Differential expression of microRNAs in dormant bud of tea [Camellia Sinensis (L.) O. Kuntze]. Plant Cell Rep. 2014: 33(7):1053-69.

5. Kakkar RK, Nagar PK. Distribution and changes in endogenous polyamines during winter dormancy in tea (Camellia Sinensis (L.) O Kuntze). J Plant Physiol. 1997;151(1):63-7.

6. Nagar PK, Shweta S. Changes in endogenous auxins during winter dormancy in tea (Camellia Sinensis (L.) O. Kuntze). Acta Physiol Plant. 2006; 28(2):165-9.

7. Thirugnanasambantham K, Prabu G, Palanisamy S, Chandrabose SRS, Mandal AKA. Analysis of dormant bud (Banjhi) specific Transcriptome of tea ( Camellia Sinensis (L.) O. Kuntze) from CDNA library revealed dormancyrelated genes. Appl Biochem Biotechnol. 2013;169(4):1405-17.

8. Wang X, Yang Y, Chen L, Ma C, Yao M. Construction and preliminary analysis of the suppression subtractive hybridization CDNA libraries between dormant and sprouting buds of tea plant(Camellia Sinensis). J Tea Sci. 2010; 30(2):129-35.

9. Lee LS, Choi JH, Son N, Kim SH, Park JD, Jang DJ, Jeong Y, Kim HJ. Metabolomic analysis of the effect of shade treatment on the nutritional and sensory qualities of green tea. J Agric Food Chem. 2013;61(2):332-8.

10. Bielenberg DG, Wang YE, Li Z, Zhebentyayeva T, Fan S, Reighard GL, Scorza $R$, Abbott AG. Sequencing and annotation of the evergrowing locus in peach [Prunuspersica (L.) Batsch] reveals a cluster of six MADSbox transcription factors as candidate genes for regulation of terminal bud formation. Tree Genet Genomes. 2008;4(3):495-507.

11. Jiménez S, Li Z, Reighard G, Bielenberg DG. Identification of genes associated with growth cessation and bud dormancy entrance using a dormancy-incapable tree mutant. BMC Plant Biol. 2010;10(42):25.

12. Li Z, Reighard GL, Abbott AG, Bielenberg DG. Dormancy-associated MADS genes from the EVG locus of peach [Prunuspersica (L.) Batsch] have distinct seasonal and photoperiodic expression patterns. J Exp Bot. 2009;60(12): 3521-30.

13. Hoenicka $\mathrm{H}$, Nowitzki $\mathrm{O}$, Hanelt $\mathrm{D}$, Fladung M. Heterologous overexpression of the birch FRUITFULL-like MADS-box gene BPMADS4 prevents normal senescence and winter dormancy in Populustremula L. Planta. 2008;227(5): 1001-11. 
14. Yang Y. Chinese tea culture. Shanghai Scientific and Technical Publishers; 2005. p 157-60. In Chinese.

15. Bevan M, Bancroft I, Bent E, Love K, Goodman H, Dean C, Bergkamp R, Dirkse W, Van Staveren M, Stiekema W, et al. Analysis of $1.9 \mathrm{Mb}$ of contiguous sequence from chromosome 4 of Arabidopsis Thaliana. Nature. 1998;391:485-9.

16. Gao J, Fu H, Zhou X, Chen Z, Luo Y, Cui B, Chen G, Liu J. Comparative proteomic analysis of seed embryo proteins associated with seed storability in rice (Oryza Sativa L) during natural aging. Plant Physiol Biochem. 2016; 103:31-44.

17. Li Q, Huang J, Liu S, Li J, Yang X, Liu Y, Liu Z. Proteomic analysis of young leaves at three developmental stages in an albino tea cultivar. Proteome Sci. 2011;9:44-5.

18. Wen F, Zhang T, Zhang Z, Pan Y. Proteome analysis of relieving effect of gibberellin on the inhibition ofriceseed germination by salt stress. Acta Agron Sin. 2009;35(3):483-9.

19. Cheng L, Yang Y, Yu F. Descriptors and Data Standard for Tea (Camellia spp.). China Agriculture Press; 2005. p 50-9. In Chinese.

20. Wang $X$. Principles and techniques of plant physiology and biochemistry experiment. Beijing: Higher Education Press; 2006. p. 202-4. In Chinese

21. Allen DJ, Ort DR. Impacts of chilling temperatures on photosynthesis in warm-climate plants. Trends Plant Sci. 2001;6(1):36-42.

22. Jiang ZS, Sun XQ, Ai XZ, Wang ML, Bi HG, Wang HT. Responses of Rubisco and Rubisco activase in cucumber seedlings to low temperature and weak light. Ying Yong Sheng Tai Xue Bao. 2010;21(8):2045-50.

23. Wang Z, Guo C, Ren H. Profilins in plant cells. J Plant Physiol Mol Biol. 2006; 32(3):261-70. Article in Chinese

24. Li J, Blanchoin L, Staiger CJ. Signaling to actin stochastic dynamics. Annu Rev Plant Biol. 2015;66:415-40.

25. Sohn RH, Goldschmidt-Clermont PJ. Profilin: at the crossroads of signal transduction and the actin cytoskeleton. BioEssays. 1994;16(7):465-72.

26. Braun M, Baluska F, Witsch MV, Menzel D. Redistribution of actin, profilin and phosphatidylinositol-4, 5-bisphosphate in growing and maturing root hairs. Planta. 1999;209(4):435-43.

27. Bankaitis VA, Aitken JR, Cleves AE, Dowhan W. An essential role for a phospholipid transfer protein in yeast Golgi function. Nature. 1990; 347(6293):561-2.

28. Bohme K, Li Y, Charlot F, Grierson C, Marrocco K, Okada K, Laloue M, Nogue F. The Arabidopsis COW1 gene encodes a phosphatidylinositol transfer protein essential for root hair tip growth. Plant J. 2004;40(5):686-98.

29. Griac P, Holic R, Tahotna D. Phosphatidylinositol-transfer protein and its homologues in yeast. Biochem Soc Trans. 2006;34(Pt 3):377-80.

30. Li C, Gu L, Gao L, Chen C, Wei CQ, Qiu Q, Chien CW, Wang S, Jiang L, Ai LF, et al. Concerted genomic targeting of H3K27 demethylase REF6 and chromatin-remodeling ATPase BRM in Arabidopsis. Nat Genet. 2016;48(6): 687-93.

31. Torres-Padilla ME, Parfitt DE, Kouzarides T, Zernicka-Goetz M. Histone arginine methylation regulates pluripotency in the early mouse embryo. Nature. 2007:445(7124):214-8.

32. Santamaría ME, Hasbún R, Valera MU, Meijón M, Valledor L, Rodríguez UL, Toorop PE, Cañal MJ, Rodríguez R. Acetylated H4 histone and genomic DNA methylation patterns during bud set and bud burst in Castanea Sativa. Plant Physiol. 2009;166:1360-9.

33. Fang W, Zou Z, Hou X, Zhang D, Duan Y, Yang Y, Li X. Cloning and sequence analysis of cold-induced $\mathrm{H} 1$-histone gene from Camellia Sinensis. Acta Botan Boreali-Occiden Sin. 2009;29(8):1514-9. Article in Chinese

34. Affolter M, Pyrowolakis G. elF4A goes beyond translation. Nat Cell Biol. 2006; 8(12):1319-21.

35. Rogers GW, Lima WF, Merrick WC. Further characterization of the helicase activity of elF4A. Substrate specificity. J Biol Chem. 2001;276(16):12598-608.

36. Li J, Li W. A novel function of drosophila elF4A as a negative regulator of Dpp/BMP signalling that mediates SMAD degradation. Nat Cell Biol. 2007; 8(12):1407-14

37. Boussemart L, Malka-mahieu H, Girault I, Allard D, Hemmingsson O, Tomasic G, Thomas M, Basmadjian C, Routier E, Kamsu-Kom N, et al. elF4F is a nexus of resistance to anti-BRAF and anti-MEK cancer therapies. Nature. 2014; 513(7516):105-9.

38. Wolfe AL, Singh K, Zhong Y, Drewe P, Rajasekhar VK, Sanghvi VR, Mavrakis KJ, Jiang M, Roderick JE, Van der Meulen J, et al. RNA G-quadruplexes cause elF4A-dependent oncogene translation in cancer. Nature. 2014;513(7516): $65-70$.
39. Kuo SH, Hsu CH, Chen LT, YS L, Yeh PY, Jeng HJ, Gao M, Yeh KH, Cheng AL. Lack of compensatory PAKT activation and elF4E phosphorylation of lymphoma cells towards mTOR inhibitor, RAD001. Eur J Cancer. 2011;47(8): 1244-57.

40. Osborne TS, Ren L, Healey JH, Shapiro LQ, Chou AJ, Gorlick RG, Hewitt SM, Khanna C. Evaluation of elF4E expression in an osteosarcoma specific tissue microarray. J Pediatr Hematol Oncol. 2011;33(7):524-8.

41. Tuteja N, Vashisht AA, Tuteja R. Translation initiation factor 4A: a prototype member of dead-box protein family. Physiol Mol Biol Plants. 2008;14(1-2): $101-7$.

42. Rolland F, Baenagonzalez E, Sheen J. Sugar sensing and signaling in plants: conserved and novel mechanisma. Annu Rev Plant Biol. 2006;57(1):e0117.

43. Truffault V, Gest N, Garchery C, Florian A, Fernie AR, Gautier H, Stevens RG. Reduction of MDHAR activity in cherry tomato suppresses growth and yield and MDHAR activity is correlated with sugar levels under high light. Plant Cell Environ. 2016;39(6):1279-92.

44. Saravitz DM, Pharr DM, Carter TE. Galactinol synthase activity and soluble sugars in developing seeds of four soybean genotypes. Plant Physiol. 1987; 83(1):185-9.

45. Sasha AS, Dinesh C. The DHQ-dehydroshikimate-SDH-shikimate-NADP(H) complex: insights into metabolite transfer in the Shikimate pathway. Cryst Growth Des. 2007:7(11):2153-60.

46. Chua CS, Biermann D, Goo KS, Sim TS. Elucidation of active site residues of Arabidopsis Thaliana flavonol synthase provides a molecular platform for engineering flavonols. Phytochemistry. 2008;69(1):66-75.

47. Wang YS, Gao LP, Shan Y, Liu YJ, Tian YW, Xia T. Influence of shade on flavonoid biosynthesis in tea (Camellia Sinensis(L.) O. Kuntze). Sci Hortic. 2012;141:7-16.

48. Agati G, Tattini M. Multiple functional roles of flavonoids in photoprotection New Phytol. 2010;186(4):786-93.

49. Lillo C, Lea US, Ruoff P. Nutrient depletion as a key factor for manipulating gene expression and product formation in different branches of the flavonoid pathway. Plant Cell Environ. 2008;31(5):587-601.

\section{Submit your next manuscript to BioMed Central and we will help you at every step:}

- We accept pre-submission inquiries

- Our selector tool helps you to find the most relevant journal

- We provide round the clock customer support

- Convenient online submission

- Thorough peer review

- Inclusion in PubMed and all major indexing services

- Maximum visibility for your research

Submit your manuscript at www.biomedcentral.com/submit
) Biomed Central 